\title{
MOX Lead Assembly Fabrication at the Savannah River Site
}

by

R. L. Geddes

Westinghouse Savannah River Company

Savannah River Site

Aiken, South Carolina 29808

D. L. Spiker

A. P. Poon

This paper was prepared in connection with work done under the above contract number with the U.S. Department of Energy. By acceptance of this paper, the publisher and/or recipient acknowledges the U.S. Government's right to retain a nonexclusive, royalty-free license in and to any copyright covering this paper, along with the right to reproduce and to authorize others to reproduce all or part of the copyrighted paper. 


\section{$\because \because \cdots$ \\ DISTCLAIMER}

This report was prepared as an account of work sponsored by an agency of the United States Government. Neither the United States Government nor any agency thereof, nor any of their employees, makes any warranty, express or implied, or assumes any legal liability or responsibility for the accuracy, completeness, or usefulness of any information, apparatus, product, or process disclosed; or represents that its use would not infringe privately owned. rights. Reference herein to any specific commercial product, process, or service by trade name, trademark, manufacturer, or otherwise does not necessarily constitute or imply its endorsement, recommendation, or favoring by the United States Government or any agency thereof. The views and opinions of authors expressed herein do not necessarily state or reflect those of the United States Government or any agency thereof.

This report has been reproduced directly from the best available copy.

Available to DOE and DOE contractors from the Office of Scientific and Technical Information, P. O. Box 62, Oak Ridge, TN 37831; prices available from (423) 576-8401.

Available to the public from the National Technical Information Service, U. S. Department of Commerce, 5285 Port Royal Road, Springfield, VA 22161. 


\section{DISCLAIMER}

Portions of this document may be illegible electronic image products. Images are produced from the best available original document. 
NMP - PLS - 970143

RIDS\#685/RSM\#10040

Ret. Permanent, offer

to NARA in 25 yrs.

\section{MOX LEAD ASSEMBLY FABRICATION \\ AT THE} SAV́VANAH RIVER SITE

Westinghouse Savannah River Company

December, 1997

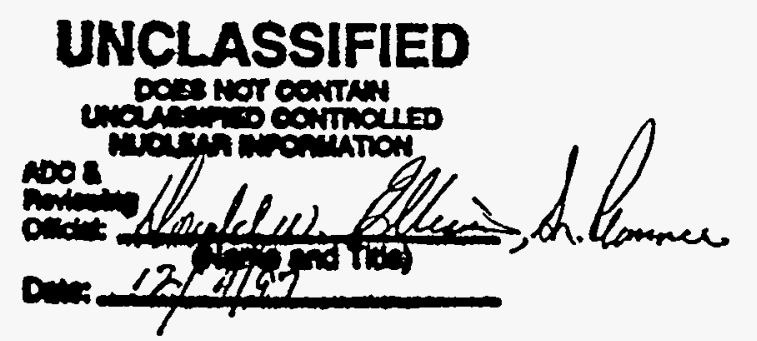




\section{TABLE OF CONTENTS}

\section{INTRODUCTION}
a. Proposed Option
b. Executive Summary

2. FACILITY DESCRIPTION
a. Existing Facility Status
b. Previous Use
c. Advantages for MOX Fabrication Utilization

3. SITE INFRASTRUCTURE
a. Utilities
b. Security
c. Fire Protection
d. Analytical Laboratories
e. Waste Handling
f. Support Services
g. Regulation \& Permitting
h. Safety

4. PROCESS INTERFACE DESCRIPTION
a. Feed Material Receiving
b. Feed Storage
c. Blending
d. Pellet Production \& Inspection
e. Rod Assembly \& Inspection
f. Rod Storage
g. Bundle Assembly
h. Bundle Storage
I. Packaging \& Shipping
j. Waste Handling

5. PROPOSED FACILITY MODIFICATION
a. To Install MOX Fuel Fabrication Equipment
b To Accomplish DOE Order Compliance

6. RESOURCES AND MANPOWER DISCUSSION
a. Design
b. Construction
c. Operation 


\section{TABLE OF CONTENTS (Continued)}

\section{ENVIRONMENTAL COMPLIANCE}
a. Permitting
b. Effluent Monitoring
c. Waste Generation

8. COST \& SCHEDULE

9. VARIANCE FROM BASELINE DISCUSSION
a. Site Variances that Increase Cost or Schedule
b. Site Variances that Decrease Cost or Schedule
c. Facility Variances that Increase Cost or Schedule
d. Facility Variances that Decrease Cost or Schedule

10. COST AND SCHEDULE RISK

11. CONCLUSIONS

ATTACHMENTS 


\section{LIST OF ATTACHMENTS}

1. SRS SITE MAP

2. CATEGORY I FACILITY SITE MAP

3. NON-CATEGORY I FACILITY MAP (FB-LINE)

4. NON-CATEGORY I FACILITY MAP (773-A)

5. CATEGORY I FACILITY BLOCK FLOW DIAGRAM

6. NON-CATEGORY I FACILITY OPTION BLOCK FLOW DIAGRAM

7. SRS WASTE TREATMENT FACILITIES 
Westinghouse Savannah River Company

NMP-PLS-970143

MOX Lead Assembly Fabrication

December, 1997

at the Savannah River "ite

Page 5 of 48

\section{INTRODUCTION}

The U. S. Department of Energy (DOE) announced its intent to prepare an Environmental Impact Statement (EIS) under the National Environmental Policy Act (NEPA) on the disposition of the nation's weapon-usable surplus plutonium. This EIS is tiered from the Storage and Disposition of WeaponsUsable Fissile Material Programmatic Environmental Impact Statement issued in December 1996, and the associated Record of Decision issued on January, 1997. The EIS will examine reasonable alternatives and potential environmental impacts for the proposed siting, construction, and operation of three types of facilities for plutonium disposition. The three types of facilities are: a pit disassembly and conversion facility, a facility to immobilize surplus plutonium in a glass or ceramic form for disposition, and a facility to fabricate plutonium oxide into mixed oxide (MOX) fuel.

As an integral part of the surplus plutonium program, Oak Ridge National Laboratory (ORNL) was tasked by the DOE Office of Fissile Material Disposition (MD) as the technical lead to organize and evaluate existing facilities in the DOE complex which may meet MD's need for a domestic MOX fuel fabrication demonstration facility. The Lead Assembly (LA) facility is to produce $1 \mathrm{MT}$ of usable test fuel per year for three years. The Savannah River Site (SRS) as the only operating plutonium processing site in the DOE complex, proposes two options to carry out the fabrication of MOX fuel lead test assemblies: an all Category I facility option and a combined Category I and non-Category I facilities option.

\section{1.a. Proposed Options}

Two options are being proposed: (1) an all Category I option for which all operations for the manufacture of the lead test assembly will be performed in an existing modified Category I facility within a single Material Access Area (MAA), and (2) a non-Category I option in which parts of the operation will be conducted in an existing Category I facility and other parts will be conducted in Category II or Category III facilities.

A SRS site map (Attachment 1) shows the relative area locations of the two proposed options. 
Westinghouse Savannah River Company

NMP-PLS-970143

MOX Lead Assembly Fabrication

December, 1997

at the Savannah River Site

Page 6 of 48

\section{1.a. Proposed Options (Continued)}

\section{All Category I Facility Option}

Under this proposed option, the lead test assembly fabrication facility will be constructed in the space previously used for the Uranium Solidification Facility (USF). The USF project was canceled with $90 \%$ mechanical completion. The equipment was never placed in service and will not cause any radiological concern during removal and facility modification. The USF structural envelope including ventilation, fire protection system, security system and other support and utilities will be reviewed and reused to the extent possible.

\section{Non-Category I Facilities Option}

An all Category I facility is most desirable because all the MOX lead test assembly operations can be housed and completed in one single MAA reducing transportation, material accountability and security requirements. However, there may be cost, schedule or other advantages where a nonCategory I facility is included for some portion of the fuel fabrication process. SRS proposes an alternative where three (3) different locations will be utilized in the lead assembly fabrication: raw material receipt, blend, and powder preparation in a Category I Facility; pellet fabrication and pin loading in Category III facility; and bundle assembly and storage a Category II facility.

Several facilities in SRS are also considered as feasible candidates for the NonCategory I option in the event that unforeseen problems or future missions preclude the use of the proposed locations. For example, powder preparation may be performed in $\mathrm{H}-\mathrm{B}$ Line, and bundle assembly and storage could be located in the Plutonium Storage Facility (PSF), F-Canyon building, or the LReactor building. This multitude of options, available through permutations of existing facilities, can be configured to address any issues anticipated for the MOX LA mission.

\section{1.b. Executive Summary}

The Savannah River Site, with its infrastructure in nuclear material stabilization, defense waste processing, and environmental restoration capabilities, is a leading candidate to provide integrated management of the disposition of Weapons-Usable Fissile Material for the Department of Energy. With the Actinide Packaging and Storage Facility (APSF) under construction, SRS offers a modern facility that could be the "center of plutonium management" for both the immobilization of plutonium and the fabrication of MOX fuel for the reactor option. 


\section{1.b. Executive Summary (Continued)}

To support the DOE-MD's call for a potential MOX fuel lead test assembly fabrication facility, SRS offers both an All-Category I option and a NonCategory I option. Both options meet all the requirements in the Baseline Assumptions and Guidelines document. With the existing plutonium operation infrastructure and a highly trained work force, SRS can carry out the lead test assembly fabrication safely and cost effectively.

\section{FACILITY DESCRIPTION}

Based on pre-conceptual design assumptions several locations were evaluated as potential MOX Lead Test Assembly, Fabrication Sites. Two options are proposed, one as a Category I facility, the other an arrangement of a group of existing facilities some of which are not Category I. This group arrangement, referred to as "Non-Category I" provides a method whereby it is feasible to develop a MOX lead assembly or a minimum fuel tube fabrication program. This option utilizes a sequence of material flow and arrangement of equipment among the Savannah River Technology Center (SRTC) and the Nuclear Material Stabilization and Storage Division (NMS\&S) facilities after the preparation of the MOX powder for which reduced security requirements could be considered for a portion of the program. The work to be performed in either proposal would rely on the support facilities and infrastructure of the respective areas.

\subsection{Description of Category I Facility}

A facility located within the H-Canyon Facility in unused space constructed for the Uranium Solidification Facility (USF), but never completed, has been chosen as the recommended facility for the Category I MOX LA fabrication option.

\section{1.a. Category I Facility Status}

The existing USF process modules, de-nitration and packaging equipment along with associated interconnecting piping, electrical, and instrumentation will be removed from the facility to allow installation of the MOX LA facilities. The USF equipment was never placed in service and is not expected to be contaminated. It is anticipated that it can be removed and released to general scrap. The basic canyon, housing the USF facility, including an analytical laboratory room is available for reuse. Existing USF security systems, fire protection, electrical distribution, utilities and ventilation supply can be utilized. Access control, locker rooms, administrative space and waste management activities are available on a shared basis with HB-Line. 
Westinghouse Savannah River Company

NMP-PLS-970143

MOX Lead Assembly Fabrication

December, 1997

at the Savannah River Site

Page 8 of 48

\section{1.b. Category I Facility Previous Use}

USF facilities were never completed nor any part commissioned. The basic USF structural envelope is not currently in use. The analytical laboratory room was not used and will be essentially maintained as installed to support the MOX processing requirements. Existing USF fire protection, electrical distribution, utilities and ventilation supply are clean and unused and will be utilized. The USF space shares access control, locker rooms, administrative space and waste management activities with HB-Line. The tenant relation among the $\mathrm{HB}$-Line and $\mathrm{H}$-Canyon as landlord can be re-established.

\section{1.c. Category I Facility Advantages for MOX Fabrication Utilization}

There are several advantages in the assessment of the USF location for MOX LA fabrication.

(1) The 6000 sq. ft. space is surplus with a hardened envelope within a plutonium handling facility with active infrastructure to support the new facility.

(2) The space is not contaminated which enables the space to be modified in a cost effective manner.

(3) Construction effort can proceed as required without impact to ongoing committed missions.

(4) Co-location with HB-Line provides a convenient established near-by secure source for handling of plutonium feed for the MOX LA facility.

\subsection{Description of Non-Category I Facility.}

The proposal to consider 3 existing facility areas for MOX LA fabrication is proposed as a way to reduce the overall cost and perhaps advance the fabrication schedule by utilization of existing plant areas.

\section{2.a. Proposed MOX LA Non-Category I Facility Status}

The three areas, FB-Line, SRTC Hot Lab, and H-Canyon area are the locations suggested. Many others facilities are available and could be investigated if this approach is judged desirable. However, none of these other configurations provide a substantial improvement to the estimated costs or schedule of the proposed arrangement. 


\section{2.a. Proposed MOX LA Non-Category I Facility Status (Continued)}

(1) FB-Line - The scheduled mission of the FB-Line facility producing $\mathrm{Pu}$ metal will be complete in FY 2000, but the facility vaults and packaging operations will remain in operation through FY 2002. There are no plans to deactivate the facility within the next decade, therefore facilities essential for $\mathrm{Pu}$ feed preparation for a MOX program will be available.

(2) SRTC Hot Lab - The Lab equipment is currently being re-engineered to support the development of waste type Immobilization. The

Immobilization Hot Demo program will be complete in FY 2000 and the Lab could be available for MOX LA fabrication use.

(3) H-Canyon space adjacent to the USF facility is currently not committed for any future mission. It is used as a staging area for clean waste containers and supplies. This area is adjacent to the H-Canyon loading dock and serves as a path for incoming and outgoing material, laundry, and packaged wastes. Sufficient area is available to accommodate the proposed MOX bundle assembly and storage without interfering with existing functions.

\section{2.b. Proposed MOX LA Non-Category I Facility Previous Use}

The FB-Line is currently active and produces metal from aqueous feed. The SRTC Hot Lab is also active in handling of limited quantities of SNM for investigative purposes. The $\mathrm{H}$-Canyon is used for staging of clean waste containers and other supplies received from the adjacent loading dock.

\section{2.c. Non-Category I Facility Advantages for MOX Fabrication Utilization}

The main advantage to the Non-Category I approach is the savings and efficiencies realized by performing most of the MOX LA manufacture under reduced security requirements. Opportunities for reduced capital cost and schedule advancement may also be possible. 


\section{SITE INFRASTRUCTURE}

\section{Site General Description}

The Department of Energy's Savannah River Site (SRS) is located in the Central Savannah River Area (CSRA), which consists of nine counties in South Carolina (Aiken, Allendale, Bamberg, Barnwell and Edgefield) and Georgia (Burke, Columbia, McDuffie, and Richmond). The site's southwestern boundary is formed by the Savannah River, a historical transportation corridor and the recipient of most of the area's tributaries. The river is used primarily to support industry, recreation and natural-habitat development. SRS is situated in three major land resource areas: the Southern Piedmont, the Carolina and Georgia Sand Hills and the Atlantic Coastal Plain. This is typical of land forms that came about as a result of marine sediment deposited in central and eastern Georgia 20 to 40 million years ago.

The CSRA has short, mild winters, moderate autumns, warm springs, and warmer summers with an annual average temperature of 64 degrees Fahrenheit. The climate stays within the U.S. average range of annual precipitation (44 inches), and snowfall is rare.

In 1990, the population of the CSRA was 492,062. Most of this population lived in Aiken, Columbia and Richmond Counties. Augusta was and remains the largest city, with a population of 44,639 . In 1990, 73.3 percent of the population lived in areas classified as urban. The urban-rural mix of the region is the same as that of the United States in general. The mix in the region, however, is more urban than other areas in South Carolina and Georgia.

The population density of the region was almost twice that of the nation in 1990, with approximately equal percentages of female and male inhabitants! Thirty-seven percent of the CSRA population is classified as minority. Compared to the national average of 12 percent black and 8 percent of other ethnicity.

The region as a whole experienced steady population growth between 1970 and 1990. The estimated resident population in 1990 for the area within 10 to 50 miles of SRS was 590,000 . The estimated population in 1990 for the area within 5 miles of the site was 37,000 . 
Westinghouse Savannah River Company

NMP-PLS-970143

MOX Lead Assembly Fabrication

December, 1997

at the Savannah River Site

Page 11 of 48

\section{Site General Description (Continued)}

The 50-mile radius of safety concern is the geographical area required by Nuclear Regulatory Commission (NRC) regulatory guides and for which a Safety Analysis Report must include population information. The only people on the "limited-access" SRS are members of the work force required to accomplish DOE's mission.

The U. S. Government established SRS in 1951 for the production and processing of nuclear materials for national defense. SRS is managed as a controlled area with limited public access. Located in south central South Carolina, SRS occupies an area of approximately 310 square miles. The Savannah River forms the site's southwestern boundary for 27 miles on the South Carolina-Georgia border, and the center of SRS is approximately 22.5 miles southeast of Augusta and 19.5 miles south of Aiken, the nearest major population centers. The site includes portions of Aiken, Allendale and Barnwell counties.

Except for site facilities, land cover is a wide variety of natural vegetation types with more than 90 percent in forest land. Adjacent land is used mainly for forest, agricultural and industrial purposes; industrial uses include a commercial two-unit nuclear reactor power plant, a regional low-level waste repository and a wide variety of conventional industries.

Open fields and pine mixed with hardwood forests comprise 73 percent of the site; approximately 22 percent is wetlands, streams and two lakes; and production and support areas, roads and utility corridors account for 5 percent of the total land area. SRS includes several production, production support, service, research and development and waste management areas.

In addition to 20 major areas that have been in use at SRS for over 40 years, an additional 20 potential industrial sites have been identified and given preliminary evaluations. These range in size up to 2,200 acres. In addition, the entire site is designated as an environmental park used by ecology, forestry and archaeology groups. The original facility layout of SRS was designed to isolate major radioactive operations near the center of the site. This design created a buffer zone that reduced the risk of accidental exposure to the general public and provided security for the site. 


\section{Site General Description (Continued)}

In response to the need for DOE to make the best use of public lands under its control, the USDA's Forest Service (USFS) has conducted a program of forest management at SRS since 1952 through an interagency agreement. In fiscal year 1993, timber cuts brought the federal government approximately $\$ 4.7 \mathrm{M}$ for 25 million board feet of lumber. Cutover land is reforested as soon as possible. Approximately 1.2 million pine seedlings were planted on more than 1,969 acres in fiscal year 1994. In addition to producing timber, the forest management program contributes to enhancing environmental diversity, protecting endangered species, conserving other species, providing quality habitats for native wildlife, protecting soil and watershed values, and providing a healthy forest for environmental research.

Under DOE's National Environmental Research Park Program (NERP), scientific investigators from universities, colleges and other research organizations use SRS as an outdoor laboratory. for the study of the impact of man's activities on the environment.

Deer and hog hunts are held annually at SRS from early November through mid-December to control the resident deer and feral hog populations and to reduce animal-vehicle collisions, which are the greatest cause of on-site accidents.

The total site work force, including subcontractors, is approximately 15,050 employees in the following organizations:

- DOE-SR, which provides overall management and oversight for SRS with 551 employees,

- Westinghouse Savannah River Company (WSRC), Bechtel Savannah River, Inc. (BSRI), BNFL and B\&W which manage and operate SRS for DOE with approximately 13,200 employees, including subcontractors,

- Wackenhut Services, Inc. (WSI), which provides and manages the site security force of 732 employees,

- SREL, which provides site ecological evaluations and research with about 197 employees, and

- The Savannah River Forest Station (SRFS), an independent unit of the USFS, which manages the site's natural resources with 89 employees. 


\section{Site General Description (Continued)}

- The Corp. of Engineers and others account for 278 employees.

Other DOE-SR subcontractors -- including the U. S. Army Corps of Engineers, Haliburton NUS Environmental Corporation, Science Applications International Corporation, Systematic Management Services, Stone \& Webster and World Computers -- total about 396 employees.

Other employers -- including the University of South Carolina Institute of Archaeology and Anthropology, the USDA's Soil Conservation Service, and the South Carolina Fish and Wildlife Service -- total approximately 25 employees. Attachment 1 shows the distribution of the SRS population by area.

SRS contains approximately 2,862 buildings, 234 of which are considered surplus buildings in the Savannah River Inventory and Assessment. An additional 4,800 supporting facilities include non-permanent buildings and other structures such as bridges, monitoring wells, and pump stations. More than 60 percent of the site's building areas are at least 40 years old. Condition Assessment Surveys have been initiated in fiscal year 1994 as part of the Capital Asset Management Process to better define building conditions and needs.

Key elements of the SRS infrastructure are as follows:

- General-purpose facilities, including permanent on-site facilities, on-site trailers, and off-site leased office space

- Analytical laboratories

- Railroad network

- Dams, lakes and ponds

- Electrical and steam generation and supply systems

- Process, domestic and cooling water systems

- Sanitary waste treatment and disposal systems

- Ecology laboratories

- Roads and bridges

- Other infrastructure, including telecommunications, emergency response, medical, environmental monitoring, fire protection, laundry, construction shops and warehouses. 
Westinghouse Savannah River Company

NMP-PLS-970143

MOX Lead Assembly Fabrication

December, 1997

at the Savannah River Site

Page 14 of 48

\section{3.a. Utilities}

\section{Electrical Power}

The existing $115 \mathrm{kV}$ and $13.8 \mathrm{kV}$ electric power distribution systems provide a reliable source of electrical power to all plant facilities. .

The $115 \mathrm{kV}$ transmission system substations and lines are connected in several modified loops. This arrangement provides all critical reactor and other process areas with redundant sources of power. The parallel 115/13.8 and $115 / 4.16 \mathrm{kV}$ transformers and associated busing and feeders supplying each facility have the capacity to supply the entire load individually. This provides increased reliability and better maintainability.

Service factor from the grid has routinely been seven nines $(99.99999 \%)$ for SRS.

The power distribution at SRS provides a reliable source of power to all processes on site including the $\mathrm{H}$-Canyon building. The electrical power is transmitted throughout the site at 115,000 volts $(115 \mathrm{kV})$. The $115 \mathrm{kV}$ transmission system consists of wooden poles, phase conductors, ground conductors to protect the phase conductors from direct lightening strikes, insulators, pole line hardware, wooden crossarms, etc.

The system contains approximately 90 miles of $115 \mathrm{kV}$ overhead transmission lines forming several loops, and containing five switching stations $(41,15,52$, 53 and 54), eight loop stations (11,12,13,14 and 15 which supply the reactor areas and 21, 22 and 71 which supply other process areas), and four radial stations (61, 63 and 66 which supply the reactor cooling water pumping stations and 72 which is in an administrative area.

A means of switching equipment and isolating electrical faults is provided by oil immersed circuit breakers. Additional isolation is provided by motor and manually operated air disconnect horn gap switches used for maintenance purposes. The $115 \mathrm{KV}$ overhead transmission system is one of the most reliable parts of the power distribution system on the site. Redundant $115 \mathrm{KV}$ power service is provided to all areas. This assures operational and maintenance flexibility. 


\section{3.a. Utilities (Continued)}

\section{Telecommunications}

Telecommunications capabilities on the SRS support the integration of voice and data services both on and off the site. These resources provide efficient access to site, DOE, national and global communications. The Replacement Telecommunications System project completed a total system upgrade in fiscal year 1995 and provided capacity to support additional operations such as MOX LA manufacturing without additional upgrades being needed. The enhancements were essential to meeting the site's voice and data transfer demands. Information Resource Management infrastructure projects, Network Operations and Replacement Telecommunications System sections share responsibility for all project and operational aspects of the site's telecommunications network. Areas and buildings are interconnected with intra- and inter-area cable and fiber facilities.

Appropriate site personnel, such as Emergency Response Team members, are equipped with pagers, voice mail system, and computer network mail. S\&S personnel have redundant radio and other communication capability.

\section{Steam}

Many of the SRS facilities use steam for processing and space heating. The steam supply is provided via a site-wide distribution network of elevated steam lines. Steam is generated at a central main generation facility and then provided as needed to process and support buildings via the steam line network. The MOX LA manufacturing proposal will not require any additional steam beyond that currently consumed by the existing facilities.

\section{Process / Domestic Water and Sanitary Waste Disposal}

SRS has an extensive system of wells and pumping stations to provide water to the various facilities on the site. MOX operations within these existing buildings will not impact current supplies of water. Sanitary waste disposal capacities for the proposed facilities will not be adversely affected by the inclusion of the MOX LA manufacturing mission. 
3.b. Security

\section{Protective Force}

Wackenhut Services, Incorporated (WSI) has been contracted by DOE to provide security support services for the 300 square mile Savannah River Site (SRS). WSI is currently providing protection of Category I quantities of Special Nuclear Materials (SNM) throughout the site. Therefore, WSI has the personnel, experience, and equipment necessary to provide protection of Category I quantities of SNM in the proposed 221-H MOX facility.

Other services and capabilities provided by WSI include an armed and uniformed protective force to guard vital SRS areas such as reactors and chemical separations areas, as well as administrative complexes. Security inspectors control access to the site at a series of perimeter barricades and are responsible for traffic control and law enforcement within its boundaries. They carry out a spectrum of security support activities which include security patrols, apprehensions, investigations of theft and other criminal conduct, sabotage prevention and monitoring of sophisticated alarm equipment.

A Special Response Team (SRT) similar to police SWAT teams is available for emergency situations or disruptive actions. The SRT maintains a group of specially trained personnel to tactically and expeditiously respond, around the clock, to security emergencies with the purpose of neutralizing any hostile threat. The SRT ensures adequate emergency response to events involving the attempted or actual sabotage of critical facilities, theft of special nuclear material, barricaded/hostage situations and any other events threatening the security of the SRS that may be perpetrated by terrorists, criminals, psychotics, disgruntled employees, anti-nuclear extremists, etc.

The SRT has a complement of 75 personnel and operates in two 12-hour duty shifts. Each shift normally consists of one SRT lieutenant, two SRT sergeants, and 12 SRT security inspectors. Each shift is comprised of two teams; a mobile ground fire team and a helicopter fire team. Mobile ground teams rotate and are not permanently assigned to an area or zone on the SRS and are constantly on alert status for immediate deployment to any area. 


\section{3.b. Security (Continued)}

The helicopter fire team may be inserted to reinforce area security, block or interdict an adversary advance, give pursuit, or provide neutralizing firepower utilizing the helicopter's aerial door gunnery platform. The team also is used to provide increased overwatch protection for intra-plant shipment of SNM.

Prior to joining WSI, all employees go through an extensive pre-employment screening. It includes a check of police records, personal references, verification of background and citizenship, and an integrity test. Those in security positions must establish their qualifications through prior education and/or experience in law enforcement or the military. They must also meet strict medical and physical fitness standards.

WSI maintains a professional training staff to provide basic and specialized security training, physical conditioning, weapons training, and field exercises. Its facilities and equipment include training rooms, mobile training vans, rifle and pistol ranges, specialized outdoor training sites, patrol vehicles, patrol boats, helicopters, assault weapons, handguns, rifles, and communications equipment.

\section{Material Control and Accountability}

Nuclear material residing on the SRS is controlled and protected in accordance with DOE orders and directives. The existing site MC\&A administrative systems are compliant and provide a level of protection that has been confirmed to be appropriate for the material being protected. MC\&A plans are developed and approved for each accounting facility which document in detail the accounting strategy and procedures. Key measurement points are identified and any associated equipment performance criteria is specified in the appropriate facility MC\&A plan. Statistical techniques such as calculations of propagated errors, application of dynamic LEIDs (limit of error for inventory differences), tank level control charting, inventory difference standard deviation calculations; and the like are employed to ensure no material accounting trends go undetected. 
Westinghouse Savannah River Company

MOX Lead Assembly Fabrication

NMP-PLS-970143

December, 1997

at the Savannah River Site

Page 18 of 48

\section{3.b. Security (Continued)}

Site inventory records are all computerized and linked to the national nuclear material database to ensure timely updates to the national nuclear material inventory. Recent computer enhancements to the site equipment represent a continuing trend of accounting system improvements and commitment by DOEE and contractor management to control and monitor all nuclear material in a cost effective and error-free manner.

\section{Physical Security}

The SRS physical security program is also compliant with the governing DOE directives. Technical assessments of vulnerabilities are routinely performed to ensure that no threat to the site nuclear material inventory, facilities, or employees is not adequately mitigated. Access to sensitive areas, material, or information is strictly controlled and many times monitored with intrusion detection systems for additional security. Routine assessments of the physical security systems on the site are performed by the contractors, DOE, and other oversight organizations to ensure an adequate level of protection is maintained.

\section{Personnel Security Performance}

SRS S\&S performance assurance programs are currently functioning and undergo routine assessments by various oversight groups including DOE Headquarters team to ensure they are adequate to protect nuclear material and government interests on the site. Programs such as Personnel Security Assurance Program (PSAP), Operational Security (OPSEC), Technical Security Countermeasures, and the like are active and fully mature.

\section{3.c. Fire Protection}

The SRS Fire Department (SRSFD) provides a fully trained and staffed shift on duty at all times, including the safety officer (SO), independently assigned to each shift. Station 1, Headquarters, is located in 709-F which is only 3 miles from the H-Canyon building. The Fire Alarm Computer System (FACS) and dispatch center is located in 709-1F. There are 3 full-time firefighters, an emergency communications specialist, 1 paramedic, and 1 lieutenant per shift at Station 1. The primary alarm response for firefighters assigned to Station 1 is Zone 1, which includes: 200-F, H, S, Z-Areas; B-Area; E-Area; N-Area; CArea; 400-D; TNX. 


\section{3.c. Fire Protection (Continued)}

Station 2 is located in 709-A. There are 3 full-time firefighters, 1 paramedic and 1 lieutenant per shift assigned to Station 2. Firefighters in this area respond to Zone 2 alarms. Zone 2 includes: 300/700 Areas; United States Forestry Service (USFS) Areas

Station 3 is located at the intersection of Roads C and 7 in 709-1G. There are 4 full-time firefighters, one paramedic, and one lieutenant per shift at Station 3. Firefighters at this station respond to Zone 3 alarms. Zone 3 includes areas: 100-K, L, P, and R; 618-G; River Pump Station.

Each fire station responds as backup to the other stations.

The SRSFD Firefighter Training Facility is located in 411-D. 411-D houses the Assistant Chief -Training, EMS Director, HAZMAT, fire, and rescue training specialists. Classroom facilities and a training ground are provided for instruction of site and SRSFD personnel.

709-C houses SRSFD managerial, administrative and clerical staff, the Chief, Assistant Chief -Emergency Response, Assistant Chief - Prevention, and officers for procedures, work control, and maintenance.

In summary, the SRS fire department can be expected to adequately and promptly respond in both manpower and equipment to a fire at the MOX LA facility.

\section{3.d. Analytical Laboratories}

The MOX analytical requirements are intended to be carried out in laboratory facilities to be located within or adjacent to the MOX facility. However, shipping procedures are well established and capabilities are operational to utilize existing laboratories for backup support. Samples are routinely shipped from various facilities to the Central Laboratory $(772-F / 1 F)$ and to SRTC (773-A) following existing shipping procedures and controls. 
Westinghouse Savannah River Company

NMP-PLS-970143

MOX Lead Assembly Fabrication

December, 1997

at the Savannah River Site

Page 20 of 48

\section{3.d. Analytical Laboratories (Continued)}

The SRS MOX proposal includes extensive on-line and at-line process laboratory functions in the facility. SRS has extensive capability in similar site laboratories located at SRTC and across the site which can provide backup and Quality Control functions as well as a source of training and cross calibration. These laboratories could also provide the MOX facilities various analytical services needed for personnel monitoring, industrial hygiene, and environmental protection.

The existing on-site laboratories (772-F/1F and 773-A complex) have the instrumentation in place to support the majority of the required analyses in a timely fashion. Some of these analytical methods are not routinely used at the present time. Additional instrumentation would have to be acquired and methods developed for specific analyses.

The Central Laboratory is a fully functional laboratory providing process control, accountability, nuclear safety and product specification support for SRS's various operating facilities. These include but are not limited to FCanyon, FB-Line, H-Canyon, HB-Line, and High Level Waste Tank Farms. All instruments are routinely calibrated, lab technicians are qualified through ongoing training programs and a robust Quality Control program is in place.

\section{3.e. Waste Handling .}

High-specific activity TRU waste will be packaged in drums and other special containers by the generator. The waste that meets waste acceptance criteria for WIPP will be classified as certifiable. Certifiable waste will be assayed, $x$-rayed, and placed in interim storage on concrete pads until shipment to WIPP. Non-certified waste will be assayed and placed in storage until the (future) TRU Waste Facility becomes operational. At that time the non-certified waste will be repackaged and certified for shipment to WIPP.

Low-specific activity TRU waste will be collected by the generator in B-25 (90 $\mathrm{ft}^{3}$ metal) boxes and transported to the Low Level Waste Disposal Facility. Compactible waste will be packaged in $5.3 \mathrm{ft}^{3}$ cardboard boxes, compacted (in H-Area), and transported to the LLW Disposal Facility. Here, the waste will then be disposed of in state-of-the-art concrete vaults. 


\section{3.e. Waste Handling (Continued)}

SRS manages waste materials regulated under RCRA, a comprehensive law requiring stringent management of hazardous waste/constituents. The Hazardous and Solid Waste Amendments were passed in 1984 to further augment RCRA.

Regulated units are surface impoundments, landfills, and waste piles (collectively termed "land disposal units") that have received hazardous waste since November 19, 1980, and that require RCRA operating or postclosure permits. Nonregulated units, termed Solid Waste Management Units, may include any activity where hazardous constituents may remain uncontrolled and potentially released to the environment. Investigations and corrective actions at these units are mandated by RCRA Section 3004(u).

On December 21, 1989, SRS was placed on the National Priority List. A site included on the list falls under the jurisdiction of CERCLA, as amended by the Superfund Amendments and Reauthorization Act of 1986. These acts impose requirements for the remediation of hazardous substance releases and of inactive hazardous waste disposal sites. The National Oil and Hazardous Substances Pollution Contingency Plan (40 CFR 300) was established under Section 105 of CERCLA. Its purpose is to provide the organizational structure and procedures required to prepare for and respond to discharges of oil and releases of hazardous substances, pollutants and contaminants.

According to Section 120 of CERCLA, DOE has negotiated a Federal Facility Agreement (FFA) with EPA and SCDHEC to coordinate remedial activities at SRS into one comprehensive strategy that fulfills both RCRA 3004(u) and CERCLA investigation and remedial action requirements. Figure 10 shows the location of RCRA Facility Investigation/Remedial Investigation units listed in the FFA, which was executed January 15, 1993, with an effective date of August 16, 1993.

FFCA resulted in a "Site Treatment Plan" which was approved on a legally mandated schedule in 1995.

Of special significance is that the STP designates SRS as one of DOE's main centers of mixed waste treatment. 


\section{3.e. Waste Handling (Continued)}

The SRS Site Evaluation List, Appendix G, of the FFCA, identifies areas that will require an initial evaluation to determine if remedial action is necessary. Approximately 300 such areas have been identified as potential waste units at SRS. Appendix C, the RCRA/CERCLA Units List, identified waste units that will be subject to the integrated remedial investigation program specified in the FFA. Appendix $\mathrm{H}$ of the FFA lists the RCRA-regulated units subject to corrective action under the South Carolina - designated program.

SRS is in the process of coding waste sites according to the FFA schedule. The F-Area Burning/Rubble Pits, the D-Area Burning/Rubble Pits, the Burma Road Rubble Pit, the Old F-Area Seepage Basin, the Silverton Road Waste Site, the M-Area West, and the L-Area Oil/Chemical Basin and Acid/Caustic Basin have an FFA commitment for a "Corrective Measure Study/Feasibility Study Report."

The existing sewage treatment plants recently have been upgraded through purchase of commercial package systems. These have adequate capacity to support the addition of a MOX mission to the proposed facilities.

\section{3.f. Support Services}

\section{Site Training}

SRS training embraces hundreds of functions and skills. Before reporting to work, each new employee receives training about the site, radiation, health protection and other important topics.' In some cases, employees complete specific training as a job prerequisite.

Site facility operators, such as separations plant workers, reactor operators and DWPF and waste management personnel, require intensive training specific to their jobs.

A new Site Training Center was completed in 1994 to accommodate approximately 1,500 trainees (two shift operation), 200 instructors/trainers, and 90 training integration support personnel at SRS. The building is located on several acres of land north of and adjacent to H-Area. The building utilizes H-Area support systems, i.e., domestic water, sanitary sewer, electrical power, fire water, and site public address and alarm system. 


\section{3.f. Support Services (Continued)}

This training facility is the newest, most complete training center in the complex. The training programs provided at the facility are the only accredited programs in the DOE complex. The capabilities and programs provided by this training facility can be made available to the selected MOX contractor to provide any level of support desired. No additional training capability should be required to support MOX operations.

\section{Site Medical Services}

SRS has assembled a large on-site medical presence for the protection of employees, the prevention and treatment of injuries. The existing medical support facilities, including those located outside $\mathrm{H}$-Area, inside F-Area, and inside A-Area, are adequate to provide emergency and first aid treatment to personnel working in the proposed MOX facility. Existing first aid stations and emergency medical supplies in the respective buildings provide employees with "first line" defenses in the unusual case of injuries.

\section{Site Emergency Management}

SRS has an extensive system of emergency notification, management, and response in place. This system functions continuously, and undergoes full scale drills to verify its adequacy. Many of these drills are conducted with local and regional authorities to ensure coordinated responses.

The Savannah River Site Emergency Plan (WSRC 1994) defines appropriate response measures for the management of SRS emergencies (e.g., radiological or hazardous material accidents). It incorporates into one document the entire process designed to respond to and mitigate the consequences of a potential accident. For example, it establishes protective action guidelines for accidents involving chemical releases to keep onsite and offsite exposures as low as possible. It accomplishes minimization or prevention of exposures by minimizing time spent in the vicinity of the hazard or the release plume, keeping personnel as far from the hazard or plume as possible (e.g., using physical barricades and evacuation), and taking advantage of available shelter. 


\section{3.f. Support Services (Continued)}

Emergencies that could cause activation of all or portions of this plan and the SRS Emergency Response Office include the following:

- Events (operational, transportation, etc.) with the potential to cause releases above allowable limits of radiological or hazardous materials.

- Events (fires, explosions, tornadoes, hurricanes, earthquakes, dam failures, etc.) that affect or could affect safety systems designed to protect site and offsite populations and the environment. The effectiveness of the emergency plan would depend on the severity of the event and the impact on the site and local infrastructure.

- Events (bomb threats, hostage situations, etc.) that affect the security posture of the site.

- Events created by proximity to other facilities such as the Vogtle Electric Generating Plant (a commercial nuclear utility across the Savannah River from the site) or nearby commercial chemical facilities.

Depending on the types of postulated accidents and the potential impacts that could result from those accidents, emergencies are classified in several categories in accordance with requirements defined in the DOE 5500 Series of Orders, as follows:

- $\quad$ Alerts are confined within the affected facility boundary; no measurable impacts to workers or members of the public outside the facility boundary are likely.

- Site Area. Emergencies are events that are in progress or that have occurred involving actual or likely major failures of facility safety or safeguards systems needed for the protection of onsite personnel, the public, the environment, or national security. Because they have the potential to impact workers at collocated facilities or members of the public in the SRS vicinity, these situations require notification of and coordination of responses with the appropriate local authorities. 


\section{3.f. Support Services (Continued)}

- General Emergencies produce consequences that require the implementation of protective actions to minimize impacts to both workers and the public. Full mobilization of all available onsite and offsite resources is usually required to deal with the event and its consequences.

In accordance with the Site Emergency Plan, SRS conducts periodic drills and exercises to develop, maintain, and test response capabilities and validate the adequacy of emergency facilities, equipment, communications, procedures and training. For example, drills occur for the following accident scenarios in the facilities or facility areas: facility or area evacuations, shelter protection, toxic gas releases, nuclear incident monitor alarms (following an inadvertent nuclear criticality), fire alarms, medical emergencies and personnel accountability (to ensure that all personnel have safely evacuated a facility or area following an emergency). DOE and Westinghouse Savannah River Company conduct and evaluate periodic drills with the following organizations or groups to ensure that they continue to maintain (from both a personnel and an equipment standpoint) the capability to respond adequately to emergency situations: first aid teams; rescue teams; fire wardens, fire response and firefighting teams; SRS medical and Health Protection personnel and personnel from the Eisenhower Army Medical Center; SRS and local communications personnel and systems; SRS security forces; and SRS Health Protection agencies.

\section{Site Transportation Services}

Major Highways/Streets/Roads

Overview/Program Description - SRS has an internal road system consisting of approximately 140 miles of primary ròads (Attachment 1), 1200 miles of secondary roads and 1,000 miles of USFS and deer hunt trails. The SRS road system accommodates traffic volumes resulting from commuters and a fleet of government vehicles. SRS road maintenance (pothole patching, resurfacing, striping, inclement weather servicing, etc.) is performed by WSRC. All primary roads on and leading to the site are "all-weather" roads, which means they are passable during all weather conditions. During the infrequent periods of ice or snow, the roads are made passable by plowing, spreading sand, etc. 


\section{3.f. Support Services (Continued)}

Off-site access to SRS is provided by four South Carolina primary roads: SC 125, the main access route from the Augusta/North Augusta/Allendale region; SC 19, which provides access to SRS from the Aiken/New Ellenton region; SC 39, which provides access from the Williston region; and SC 64, which provides access from the Barnwell region (back of Attachment 1).

South Carolina is serviced by five U. S. primary routes: I-20, I-95, I-26, I-85 and I-77. The nearest to SRS is I-20, approximately 30 miles from the center of the site.

U.S. Highway 278 passes through New Ellenton, adjacent to the site boundary. In addition, U. S. Highway 1 passes through Aiken and Augusta and U. S. Highway 301 passes through Allendale. Both extend to within 30 miles of the center of the site.

Purpose/Missions

Load Characteristics - Major SRS bridges are being upgraded to carry 200-ton loads under special conditions. These primary bridges are scheduled for completion in early calendar year 1998. As is standard with the over-the-road shipments, heavy loads to be carried on state-maintained and SRS roads require permitting, as well as preplanned route approval from the State of South Carolina and the SRS organization responsible for the roads.

Public Access Control - South Carolina primary routes provide uninhibited public access to the SRS perimeter; however, access to SRS interior roads is controlled by security barricades at entrances on major roads and locked gates on secondary roads. All occupants of a vehicle must possess a security badge issued by SRS to enter the site perimeter. SRS secondary roads near the perimeter "are controlled with locked "cattle gates" and require a perimeter security gate key for entry. In addition, the SRS security contractor, Wackenhut Services, Inc., conducts regular patrols around the site perimeter. 
Westinghouse Savannah River Company

NMP-PLS-970143

MOX Lead Assembly Fabrication

December, 1997

at the Savannah River Site

Page 27 of 48

\section{3.f. Support Services (Continued)}

Three roads on SRS property are available for public use: SRS Road 1, SC 125 and US 278. SRS Road 1 connects SC 125 to SC 19 and services the Administrative Area parking lots and SRS Road 1-A. SRS Road 1 does not have controlled entry, but access from Road 1-A to the remainder of SRS is controlled with security barricades. US 278 traverses a small northern corner of SRS. There are no primary entrance routes along this roadway and SRS secondary roads are secured with locked gates. The third public access route is SC 125, which runs northwest to southeast along the western edge of SRS. Travelers on this road, which connects North Augusta and Allendale, are not required to stop at the northern and southern security checkpoints. However, security barricades at site boundaries can be closed during emergency situations. In addition, main entrance routes along SC 125 within SRS (SRS Roads $B, 2,3$ and 6 ) are controlled with manned barricades.

\section{Railroads/Waterborne Transport}

Overview/Program Description - SRS maintains a railroad system that is adequately designed and maintained to support current and proposed facilities. The system consists of approximately 60 miles of track configured to provide access to all major operations facilities located within the site (Attachment 1). SRS rail-rolling stock consists of locomotives and rail cars to support on-site rail moves. A full-service subcontractor maintains all rails, cross ties, ballasts and subsurfaces to meet or exceed federal transportation guidelines. No tunnels or underpasses restrict the transportation of tall or wide loads.

Materials and products transported by rail to or from SRS are shipped by the Norfolk Southern Corporation and CSX Transportation, both of which have access throughout the United States, Canada and Mexico.

The SRS rail system is configured -- and has been used routinely -- to efficiently provide on-site transportation of such items as irradiated fuel, high-level contaminated equipment and waste materials, construction materials and equipment, environmental products and bulk materials, such as coal, sand, gravel, etc.

Access to the rail system is controlled by a security gate and derail system. Offsite rail deliveries are brought to the railroad classification yard for transfer to the SRS rail system. Security gates remain locked during off-shift hours. 


\section{3.f. Support Services (Continued)}

SRS has boundary access to the Savannah River, which has been used successfully to transport large, heavy loads, particularly during initial site construction and then, with less frequency, up until 1979. Prior to 1979, the U. S. Army Corps of Engineers maintained the river with a 9-foot channel. While no regular river shipments have been made since that year, special waterborne shipments were made to Augusta and SRS as recently as August 1992.

\section{3.g. Regulation \& Permitting}

The site is in compliance with NESHAP regulations for radioactive emissions. Per 40 CFR 61 Subpart $\mathrm{H}$, radionuclide emissions from any DOE facility, i.e., SRS, shall not exceed amounts that would cause any member of the public to receive in any year an effective dose equivalent of 10 $\mathrm{mrem} /$ year. SRS has not exceeded this standard since the regulation has been in place and has seen a decrease in the offsite dose over recent years. The effective dose equivalent to the nearest offsite individual resulting from all sources of radioactivity on the site in 1995 was $0.08 \mathrm{mrem}$. The Site's radionuclide NESHAP program is defined in both the Savannah River Site Radionuclide NESHAP Quality Assurance Project Plan (required by the regulation and approved by the EPA) and in The Environmental Monitoring Plan.

\section{3.h. Safety}

The SRS industrial safety program has been the envy of the DOE complex for many years. Almost without exception the site has enjoyed the reputation and the benefits of demonstrating the very best safety performance within the DOE complex. The State of South Carolina and the office of Occupational Safety and Health have recognized the SRS achievements in industrial and nuclear safety through the years. DOE Headquarters is currently assessing the site's Voluntary Protection Program for Star Status.

In the area of Radiological Safety, SRS also excels. SRS has an established ALARA. The intent of the program is to ensure that the radiation exposure of the work force and public shall be controlled such that radiation exposures are well below regulatory limits and that there are no radiation exposures without commensurate benefit. 


\section{3.h. Safety (Continued)}

The ALARA program addresses, at a minimum, the following basic elements:

- Policy - Establish commitment and participation of all management and workforce levels to the ALARA policy.

- Training - Required for managers and workers involved with any aspect of radiological operations.

- Design - Ensure integration of appropriate methods for maintaining occupational exposures ALARA during design.

- Procedure - Provides direction for maintaining occupational exposures ALARA.

- Radiological Work Planning - Integrate measures for maintaining occupational exposures ALARA for specific operations.

- Audits - Conduct comprehensive audits periodically and report results to the higher management level.

- Records - Maintain documentation and demonstrate compliance.

\section{PROCESS INTERFACE DESCRIPTION}

This chapter is divided into two sections to address the All-Category I Facility option (4.1) and the Non-Category I Fàcility option (4.2). A block flow diagram of the MOX process is provided.

The MOX lead assembly fabrication is assumed to be an all dry process that meets current commercial standards for nuclear fuel fabrication. Due to the limited mission, it is envisioned that minimum automation will be used in the process in order to minimize capital cost.

The description below is generic in nature to assist the reader in understanding the material flow within the proposed facilities and equipment layout. It is not a detailed process flow sheet for each step in the MOX fuel fabrication process. 
Westinghouse Savannah River Company.

MOX Lead Assembly Fabrication

NMP-PLS-970143

at the Savannah River Site

December, 1997

Page 30 of 48

\subsection{All Category I Option}

Under the All Category I option, all the process functions in the MOX lead assembly fabrication will be performed in a Category I facility within a single Material Access Area (MAA). The proposed facility will be located in the space the previous Uranium Solidification Facility (USF) occupied. This facility is in section 2 of the 221-H Canyon building spanning two floors with a mezzanine in between which will provide an in-process storage vault for the feed material, blended powder and pellets.

Attachment 5 shows the Category I option flow diagram.

\section{1.a. Feed Material Receiving}

A Category I quantity of material ( $\mathrm{PuO} 2)$ will be delivered by DOE Safe, Secure Transport (SST) vehicle and will be received at a state-of-the-art SST unloading and receiving facility in the Actinide Packaging and Storage Facility (APSF) in F-Area (To be completed by 09/2001). The necessary receipt and accountability procedures will be performed and the material will be placed in temporary storage until it is needed for production. The PuO2 will then be transported intra-site to the MOX lead test assembly fabrication facility.

Depleted uranium (DUO2) will probably be shipped via commercial carrier. The site has other facilities to receive and store the DUO2 until it is needed in the MOX LA fabrication.

\section{1.b. Feed Storage}

Feed storage at the MOX lead test assembly fabrication facility will be provided by the mezzanine level vault. Storage positions will be provided for the $\mathrm{PuO} 2$ containers. This vault will also be used for in-process material storage, such as batches of master blend powder, green pellets or sintered pellets.

\section{1.c. Blending}

Feed material from the mezzanine vault will be moved to the 2nd level room where the receipt glovebox is located. This room provides an additional containment for the initial powder preparation operation where $\mathrm{PuO} 2$ material is in higher quantity and concentration. 
Westinghouse Savannah River Company

NMP-PLS-970143

MOX Lead Assembly Fabrication

December, 1997

at the Savannah River Site

Page 31 of 48

\section{1.c. Blending (Continued)}

The $\mathrm{PuO} 2$ can and DUO2 pail are introduced into the feed material entrance glovebox, where lids will be opened, necessary assay functions performed, and the material weighed and batched. A batch of material will then be placed in the blender for a 30\% PuO2 master blend. Recycled MOX powder may also be added to the batch to obtain the desired blend.

After the first blend process, the powder will be sampled and processed through a milling operation in the same glovebox. Milled powder is then fed to an adjacent glovebox to be compacted, granulated, and screened. It is then introduced to a blender for the final blend to $5 \% \mathrm{PuO} 2$. A binder is also added during the final blend. The prepared MOX powder is then stored in the inprocess vault or forwarded to the pellet line.

Note that accountability and analytical functions are maintained throughout the powder preparation process.

\section{1.d. Pellet Production \& Inspection}

The $5 \% \mathrm{PuO} 2 \mathrm{MOX}$ powder from the final blend process or from the mezzanine level vault enters the pellet fabrication glovebox and is introduced into a hopper which feeds the pellet press. Pellets will be removed and stacked on trays which are stacked into green pellet boats. The boats will be covered and placed into in-process storage or loaded into the sintering furnace. The green pellets in the boat will undergo a $20 \%$ size reduction in the furnace to a specified density. The dimensions of the pellets are checked and oxygen content and density will be measured before the sintered pellets are placed in storage or transferred to the grinding and inspection glovebox. Grinding brings the pellets to the specified dimensions. Physical surface inspection and dimension verification will then be performed. Good pellets will be loaded into racks for subsequent rod loading. The pellet racks may be stored in the mezzanine level vault until they are needed for the fuel rod loading operation.

\section{1.e. Rod Assembly \& Inspection}

Rod filling, tube end decontamination, pressurization and seal welding of end caps will be performed in a work station with a multi-stage glovebox at one end. This work station will be where the pellet racks from the pellet line or from the vault will be delivered via the existing dumbwaiter. 


\section{1.e. Rod Assembly \& Inspection (Continued)}

It is assumed that fuel pins will be received with one end cap already welded. The tube will be introduced to the first compartment of the glovebox where pellets will be loaded, and the open tube end decontaminated. Next the tube will proceed to a second and third compartment where the subsequent welding and pressurization operations will be carried out to complete the pin assembly.

The fuel rods will be transferred to a helium leak test chamber and NDE station for $\mathrm{x}$-ray inspection of the seal welds. The rods are then decontaminated and undergo gamma scanning and additional inspection and tests, before they are placed in trays for storage until they are needed for bundle assembly.

\section{1.f. Rod Storage}

Fuel rods placed in sealed trays with supports will be stored on racks in the rod fabrication room until they are needed for bundle assembly.

\section{1.g. Bundle Assembly}

Bundle assembly will be performed in high bay area where it is open to the ceiling. An assembly station with a tilt table will be used for the insertion of fuel rods into the bundle assembly. Depending on the reactor selected for the lead test program, a complete assembly may be fabricated from the skeleton and other hardware with all MOX fuel rods, or bundles may be received such that only one half of the positions are to be inserted with MOX tubes. For the lead test assembly fabrication limited mission, it is envisioned that loading will be done manually one tube at a time.

\section{1.h. Bundle Storage}

Bundle storage will be provided by a hanging rack on the wall. Up to six positions will be provided for storage of bundles until they are shipped to the off-site commercial reactor. The tilt table will place the bundle in a horizontal position during assembly, then verticalize it when it is ready to be inspected and transferred to the storage location by an overhead hoist. A strongback transfer device will allow the bundle assembly to be moved to the packaging and shipping area. 


\section{. 4.1.i. Packaging \& Shipping}

Packaging and shipping will be located in $\mathrm{H}$-Canyon where a work table and hoist will be provided for transfer of the received bundle from the shipping cask to the strongback transfer device for movement to the assembly area. The completed MOX fuel assembly will also be loaded into a shipping cask in this area for off-site shipping. This area is near the canyon south loading area on ground level.

\section{1.j. Waste Handling}

Facility and equipment for waste, monitoring, treatment and packaging are located directly above the proposed MOX lead assembly fabrication facility in HB-Line and will be used to the extent possible. There is an existing waste lift and an elevator which will transport waste from the MOX facility to the HBLine facility. Attachment 7 shows the SRS waste treatment facilities.

\subsection{Non-Category I Option}

In the Non-Category I option, the process functions in the MOX lead assembly fabrication will be performed in three (3) different locations: receiving and powder preparation in FB-Line (Category I facility); pellet fabrication and pin loading in 773-A (Category III facility); and bundle assembly and storage at the south end of the H-Canyon, a Category II facility.

Attachment 6 shows the non-Category I option block flow diagram.

\section{2.a. Feed Material Receiving}

A Category I quantity of material (PuO2) will be delivered by DOE Safe, Secured Transport (SST) vehicle to a state-of-the-art SST unloading and receiving facility'in the Actinide Packaging and Storage Facility (APSF) in F-Area (To be completed by 09/2001). The necessary receipt and accountability procedures will be performed and the material will be placed in temporary storage until it is needed for production. The $\mathrm{PuO} 2$ will then be transported to the proposed FB-Line powder preparation facility.

Depleted uranium (DUO2) will probably be shipped via commercial carrier. The site has facilities to receive and store the DUO2 until it is needed in the MOX LA fabrication. 


\section{2.b. Feed Storage}

$\mathrm{PuO} 2$ feed will be stored in the APSF vault until it is needed to start a blending run. An alternate storage location will be the FB-Line vault just below the MOX powder preparation facility.

\section{2.c. Blending}

Feed material from the storage vault will be moved to the receiving and powder preparation facility on 5th level FB-Line where the receipt glovebox is located. The $\mathrm{PuO} 2$ can and the DUO2 pail will be introduced to the feed material entrance glovebox, where the lids will be opened, necessary assay and confirmatory functions performed, the material weighed, batched, and then placed in the blender for a 30\% PuO2 master blend. Recycled MOX powder may also be added to the batch to obtain the desired blend.

After the first blend process, the powder is sampled and processed through a milling operation in the same glovebox. Milled powder is then fed to an adjacent glovebox to be compacted, granulated and screened, before it is introduced to a blender for the final blend to $5 \% \mathrm{PuO} 2$. A binder is also added during the final blend. The prepared MOX powder is then packaged in the recently installed Bagless Transfer System. The 5\% MOX blend will be stored in the FB-Line vault until it is needed for pellet fabrication, then it will be transported in Category III quantity shipments to the pellet line in the 700 Area.

\section{2.d. Pellet Production \& Inspection}

Pellet production will be performed in the SRTC facility. The 5\% PuO2 MOX powder will be transported from the FB-Line vault to the process room in 773-A. The MOX powder will enter the pellet fabrication glovebox to a hopper which feeds the pellet press. Pellets will be removed and stacked on a tray to be stacked into green pellet boats. The boats will be covered and placed into in-process storage or loaded into the sintering furnace. The green pellets in the boat will undergo a $20 \%$ size reduction in the furnace to a specified density. 


\section{2.d. Pellet Production \& Inspection - (Continued)}

The dimensions of the pellets are checked and oxygen content and density will be measured before the sintered pellets are placed in storage or transferred to the grinding and inspection glovebox. Grinding brings the pellets into the specified dimensional tolerance. Physical surface inspection and dimension verification will then be performed. Good pellets will be loaded into racks for subsequent rod loading.

\section{2.e. Rod Assembly \& Inspection}

Rod filling, tube end decontamination, pressurization, and seal welding of the end cap will be performed in a work station with a multi-stage glovebox at one end. It is assumed that fuel pins will be received with one end cap already welded. The tube will be introduced to the first compartment of the glovebox where pellets will be loaded, and the tube end decontaminated. It is then moved to a second and third compartment where the subsequent pressurization and welding operations will be carried out to complete the pin assembly.

The fuel rods will be transferred to a helium leak test chamber and NDE station for $x$-ray inspection of the seal welds. The rods are then decontaminated and undergo gamma scanning and additional inspection and testing. They are then placed in trays and loaded in a intra-site shipping cask. The fuel rods will then be transported to $\mathrm{H}$-Area for bundle assembly.

\section{2.f. Rod Storage}

Fuel rods placed in sealed trays with supports will be stored on racks in the bundle assembly and storage area on the 2 nd level south end of the $221-\mathrm{H}$ Canyon.

\section{2.g. Bundle Assembly}

Bundle assembly will be performed on the 2nd level south end of the $221-\mathrm{H}$ Canyon. An assembly workstation will be used for the insertion of fuel rods into the bundle assembly. Depending on the reactor selected for the lead test program, a complete assembly may be fabricated from the skeleton and other hardware with all MOX fuel rods, or bundles may be received such that only one half of the positions are to be inserted with MOX tubes. For the lead test assembly fabrication limited mission, it is envisioned that loading will be done manually one tube at a time. 


\section{2.h. Bundle Storage}

Bundle storage will be provided by a hanging rack in the bundle assembly and storage area on the 2nd level of the $\mathrm{H}$-Canyon south end. Up to six positions will be provided for bundle storage until they are shipped to the off-site commercial reactor. From the workstation, the completed bundle assembly will be placed in a strongback and transferred horizontally by a monorail hoist to an area with the floor opens to the first level. The bundle assembly is then tilted and lowered through the floor opening to a vertical position for the inspection and gauging operation before it is placed in the vertical storage position.

\section{2.i. Packaging \& Shipping}

Packaging will be performed in the bundle assembly and storage area. The MOX fuel assembly will be loaded into shipping cask in this area and moved to the adjacent $\mathrm{H}$-Canyon southwest loading dock for off-site shipping.

\section{2.j. Waste Handling}

Facility and equipment for waste monitoring, treatment and packaging are available at all three locations for the MOX lead assembly fabrication and will be used to the extent possible. Attachment 7 shows the SRS waste treatment facilities.

\section{PROPOSED FACILITYMODIFICATION}

\section{5.a. Installation of MOX Fuel Fabrication Equipment}

\section{1.a. Category I Facility Option.}

The former USF process modules will be removed from the facility, along with associated interconnecting piping and electrical/instrumentation. The USF de-nitration and packaging equipment will also be dismantled and removed. The basic USF structural envelope including security features will be reused. The analytical laboratory room will be maintained as installed. Existing USF fire protection, electrical distribution, utilities and ventilation supply will be utilized. 


\section{1.a. Category I Facility Option - (Continued)}

Free standing gloveboxes including MOX fuel fabrication equipment will be installed in an orderly arrangement of receipt, storage, analysis, manufacture and inspection. A Category I vault storage and space to hang 6 bundles will be accommodated. An additional area allocated from Canyon operation storage space immediately south of the former USF area will be assimilated into the MOX MAA by construction of hardened confinement walls. Bundle packaging and exhaust ventilation will be designed and arranged within this space.

\section{2.a. $\quad$ Non-Category I Facility Option}

\section{2.a.1 FB-Line Description of Work}

After the FB-Line metal program is complete some FB-Line Pu metal production equipment will be dismantled and removed. Existing or modified glove box(es) will be utilized for installation of the powder preparation equipment. Existing FB-Line and 772-F laboratory analytical capability will be modified as necessary and utilized.

\section{2.a.2 SRTC Description of Work}

After the Immobilization Hot Demo is complete the equipment will be dismantled and removed. The existing immobilization glovebox (to be installed under the $\mathrm{Pu}$ immobilization hot demonstration program) will be used to contain the MOX LA fuel fabrication equipment. No significant modification to the containment glove boxes is planned. Additional glove box(es) and adjacent space will be used as required. The existing press and furnace from the immobilization equipment will be used to the extent possible as well as receipt and packaging features that remain. Additional equipment for pellet grinding and inspection, rodfill and leak check will be provided. 


\section{2.a.3 H-Canyon 2nd Level Description of Work}

The space proposed for bundle assembly and storage in $\mathrm{H}$-Canyon is an open space currently used for staging of material and supplies. A wall will be installed to partition this area and leave an access route for material and supply traffic from the adjacent loading dock. An opening will be cut in the floor to provide the required height for the vertical bundle inspection and storage functions. Monorails and hoists will be installed. Approximately 1,500 sq. $\mathrm{ft}$. of space is available to accommodate the rod storage racks, bundle assembly workstation, bundle storage, and cask loading operations. Utilities and support services are readily available from the $\mathrm{H}$-Canyon building.

\section{5. $\mathrm{b}$ To Accomplish DOE Order Compliance}

In most cases, for the MOX Lead-Assembly process and operating areas, the larger facility (221-H canyon building) housing the MOX facility is either fully compliant, currently undergoing upgrade (i.e., fire protection), or has approved compensatory measures in place. There are no outstanding compliance actions remaining for the $\mathrm{H}$-Canyon facility.

\section{6. $\quad$ RESOURCES AND MANPOWER DISCUSSION}

SRS has the resources and manpower, and a fully integrated management system to have successfully brought on line large complex production facilities such as the Defense Waste Processing Facility (DWPF) and the Replacement Tritium Facility (RTF). SRS also partners with the national laboratories, universities and industries to develop technologies and equipment in the production and material stabilization programs. The site is operated by Westinghouse Savannah River Company, with its partners Bechtel Savannah River Company, BNFL Savannah River Company, and Babcock \& Wilcox Savannah River Company. In support of the DOE's privatization initiative, SRS has demonstrated a track record of partnering with private industries in the design and construction of project work through competitive bidding. The latest example is the award of the design contract for the APSF project.

\section{6.a. Design}

SRS has an engineering department with in-house design capability. It also oversees design contracts performed by outside design contractors. Qualified design agencies, with personnel trained and qualified in SRS programs, also supplement the SRS core design capability. 


\section{6.b. Construction}

SRS has a highly skilled, well trained and qualified construction work force in a "right to work" state. Construction work may also be sub-contracted to support the DOE privatization initiative.

\section{6.c. Operation}

SRS has an operating work force with production experience and technical competency proven by over forty years of plutonium and other nuclear material management. SRS is also a leader in fully implementing improved conduct of operations in existing plutonium facilities and has set new standards in training and certifying plutonium workers. The current site population of qualified radiological workers is 4129 exempt and 4766 nonexempt personnel.

\section{ENVIRONMENTAL COMPLIANCE}

SRS has an extensive environmental surveillance program in place to ensure the safety of the public and the workers, as well as the preservation of the environment. An annual environmental report and data are published to comply with the DOE Order 5400.1, "General Environmental Protection Program". The report summarizes environmental data that characterize site environmental management performance, confirm compliance with environmental standards and requirements, and highlight significant programs and efforts.

\section{7.a. Permitting}

The MOX LA fabrication facility is part of the MOX program covered under the Surplus Plutonium Disposition EIS. The upcoming Record of Decision (ROD) in the fourth quarter of FY1998 will complete the program level NEPA requirements for the MOX LA fabrication facility.

The construction and operation of the MOX LA fabrication facility is not expected to increase current SRS emissions significantly. For effluent or waste volume which require permits, only minor modification to existing permits are expected. 


\section{7.b. Effluent Monitoring}

The proposed MOX LA fabrication facility, either the Category I option or the non-Category I option, will be located in existing facilities. These existing facilities have monitors on the facility ventilation exhaust stacks where the air is continuously monitored and alarms to notify personnel when a prescribed activity level is detected. Existing facility liquid effluent is sampled in retention basins for indications of releases before it is discharged to the NPDES permitted outfalls.

All emissions and effluents at the site are regulated by state and federal permits. Construction and operation of the MOX LA fabrication is not expected to exceed current permitted limits.

\section{7.c. Waste Generation}

See proposal questionnaire for estimated construction waste amount. Operation of the MOX LA mission under either option is not anticipated to significantly affect waste disposal operations for SRS. Waste will be generated during construction and operation of the MOX LA fabrication facility.

SRS has an extensive waste management program to properly monitor, segregate, and dispose of radiological and non-radiological wastes. TRU waste will be packaged in drums and those that meet waste acceptance criteria for WIPP will be assayed and stored on site on concrete pads until future shipment to WIPP. Low level solid waste is compacted and packaged, then stored in the on-site LLW concrete vault. Low level liquid waste will be treated in the extensive SRS liquid waste treatment systems. Attachment 7 shows the SRS waste treatment facilities.

\section{COST \& SCHEDULE}

A planning basis cost estimate and schedule for the MOX Lead Test Fabrication Facility will be developed by the Site Evaluation Team, with input from the site.

The MOX LA facility will be operated for three years to supply test fuel and then placed in standby for four years to maintain a state of readiness to produce extra fuel. 


\section{VARIANCE FROM BASELINE DISCUSSION}

TBD

9.a. Site Variances that Increase Cost or Schedule

9.b. Site Variances that Decrease Cost or Schedule

9.c. Facility Variances that Increase Cost or Schedule

9.d. Facility Variances that Decrease Cost or Schedule

\section{COST AND SCHEDULE RISK}

Cost and schedule risk will be assessed after the completion of the cost estimate and schedule by the Site Evaluation Team.

\section{CONCLUSIONS}

SRS is the site of choice for the MOX LA fabrication program. Either option proposed in this report will be supported by forty years of plutonium management experience and the best trained plutonium workers in the complex, modern support infrastructure, and unparalleled community support in the two state area. SRS can carry out the lead test assembly fabrication safely and cost effectively. 


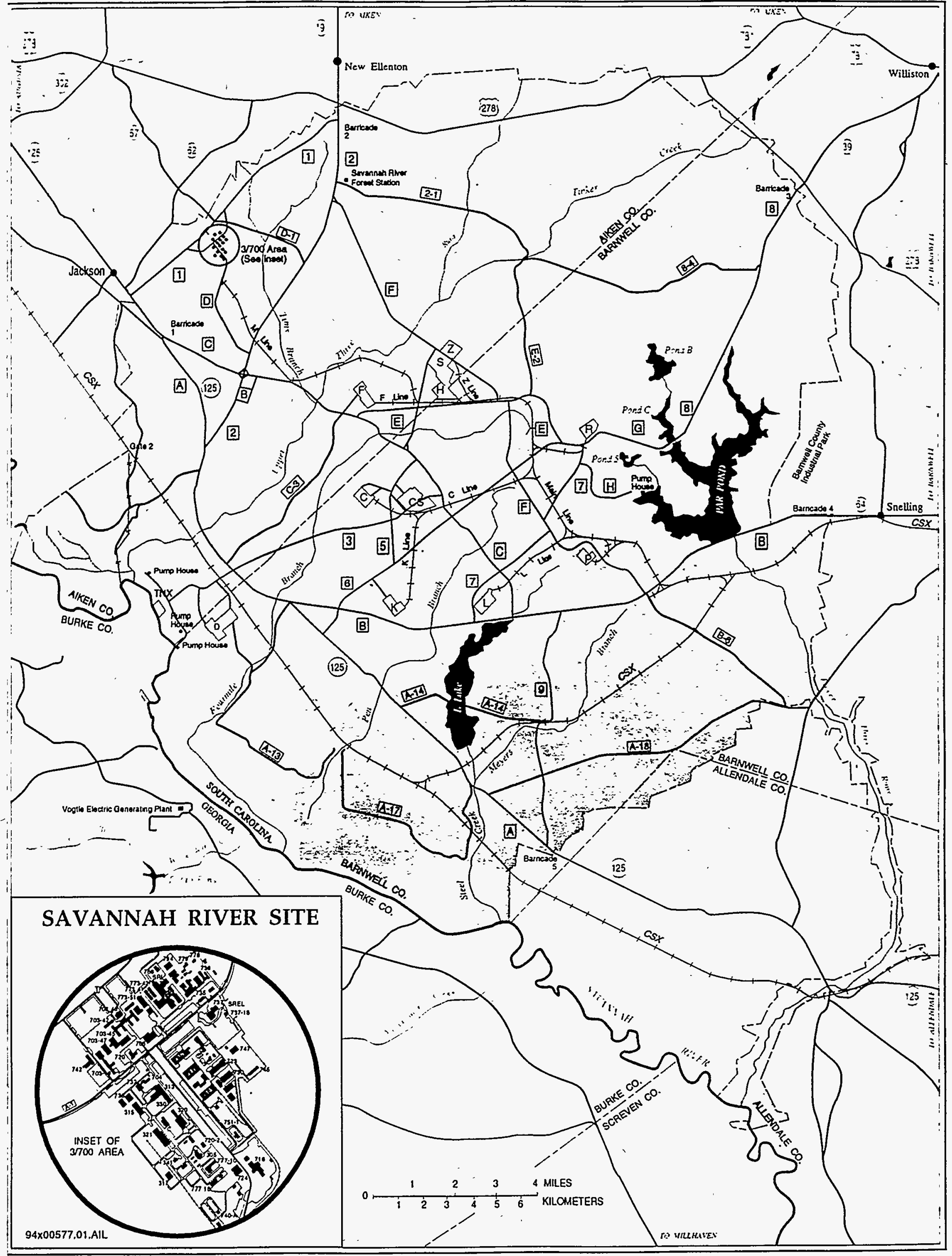


Westinghouse Savanah River Company

NMP-PLS-970143

MOX Lead Assembly Fabrication

December, 1997

at the Savannah River Site

Page 42 of 48

\title{
ATTACHMENT 1
}

\author{
SRS SITE MAP
}




\section{ATTACHMENT 2}

\section{CATEGORY 1 FACILITY SITE MAP}




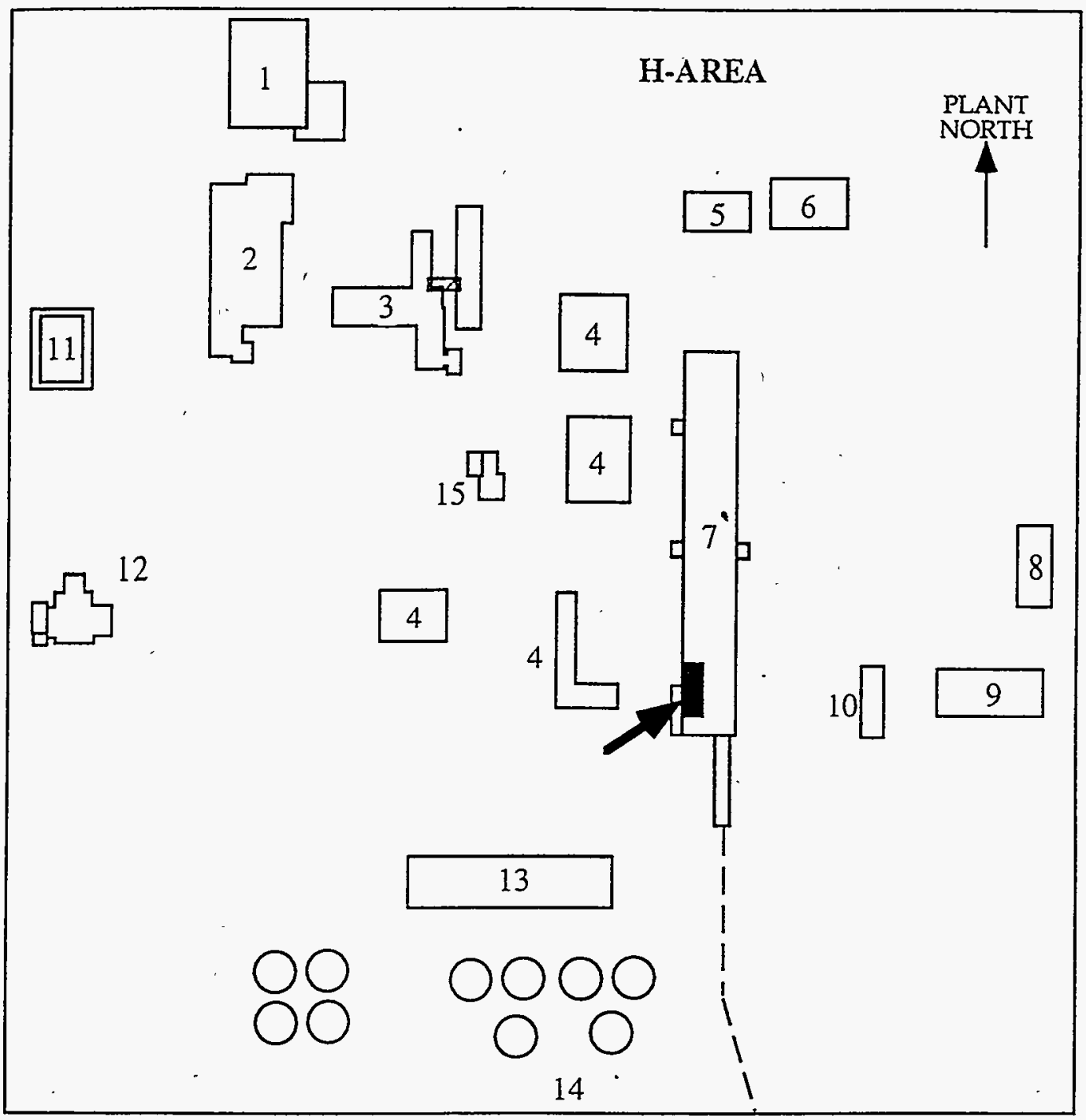

1. 233-H, Manufacturing

2. 234- $\mathrm{H}$, Manufacturing

3. 232- $\mathrm{H}$, Manufacturing

4. 703-H, 704-H, 704-H, Administration Bldgs.

5. $704-55 \mathrm{H},(5000 \mathrm{bldg}$.)

6. 704-2H, Administration Annex Bldg.

7. 221-H, Canyon Building

8. 299-H, Waste Management Maint. Facility

9. 294-H, Sandfilter

10. 292-H, Fan House

11. 235.H, Tritium Facility Office Bldg.

12. 244-H, RBOF

13. Coal Storage Area

14. Waste Storage Tanks

15. $70 \mathrm{l}-1 \mathrm{H}$ 


\section{ATTACHMENT 3}

NON-CATEGORY 1 FACILITY MAP (FB-LINE) 


\section{ATTACHMENT 3 \\ NON-CATEGORY 1 FACILITY ALTERNATIVE \\ POWDER PREPARATION LOCATION}

1. Main Substation

2. Laboratory Buildings

3. Administration Buildings

4. F-Canyon Building (Incl. PSR, NSR \& Reduction)

5. Support Facilities

6. SandFilters

7. Cooling Towers

8. Fan House

9. Stack

10. Fire Station

11. Entry Control Facility

12. Laundry

13. Mock-up Shop

14. Rail Access

15. Waste Tánk Farm

Proposed Location

for Powder Preparation
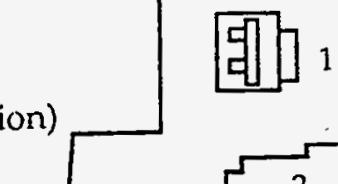

1
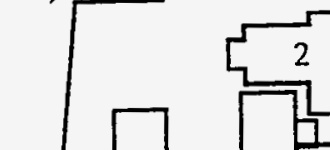

7.

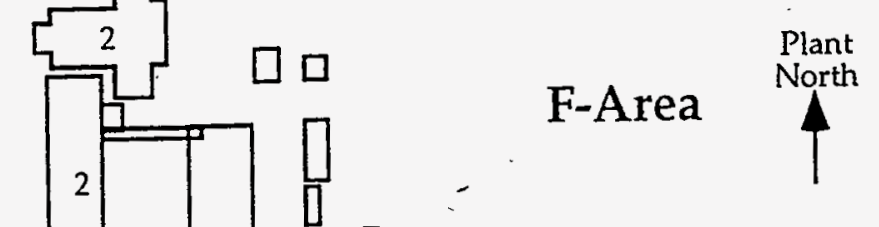

3

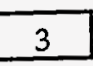

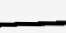

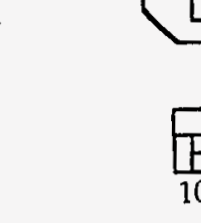

1.

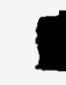

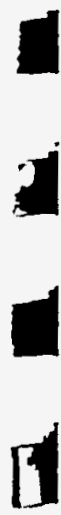

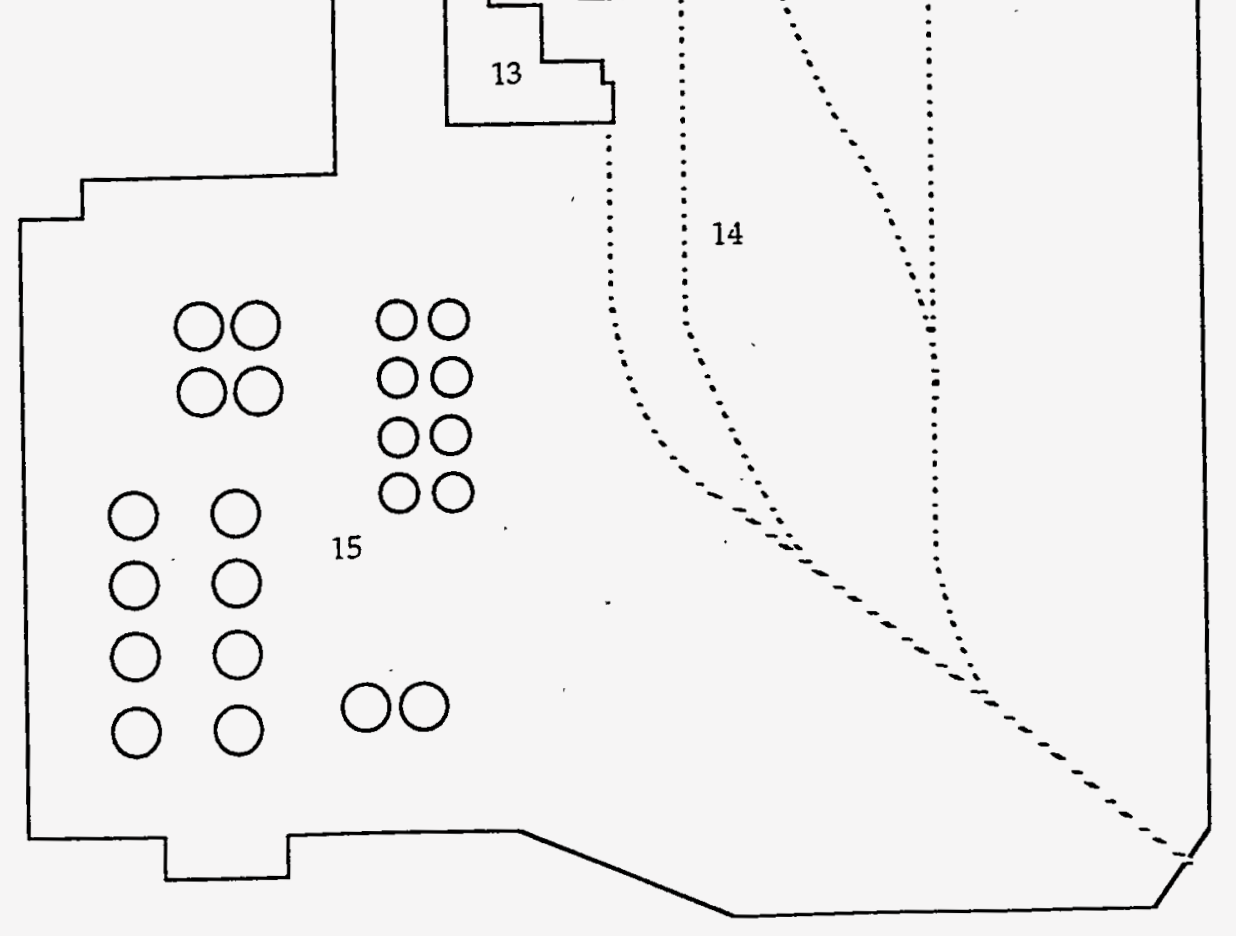

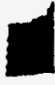




\section{ATTACHMENT 4}

NON-CATEGORY 1 FACILITY MAP (773-A) 


\section{ATTACHMENT 4 NON-CATEGORY 1 FACILITY ALTERNATIVE PELLET FABRICATION/RODFILL LOCATION}

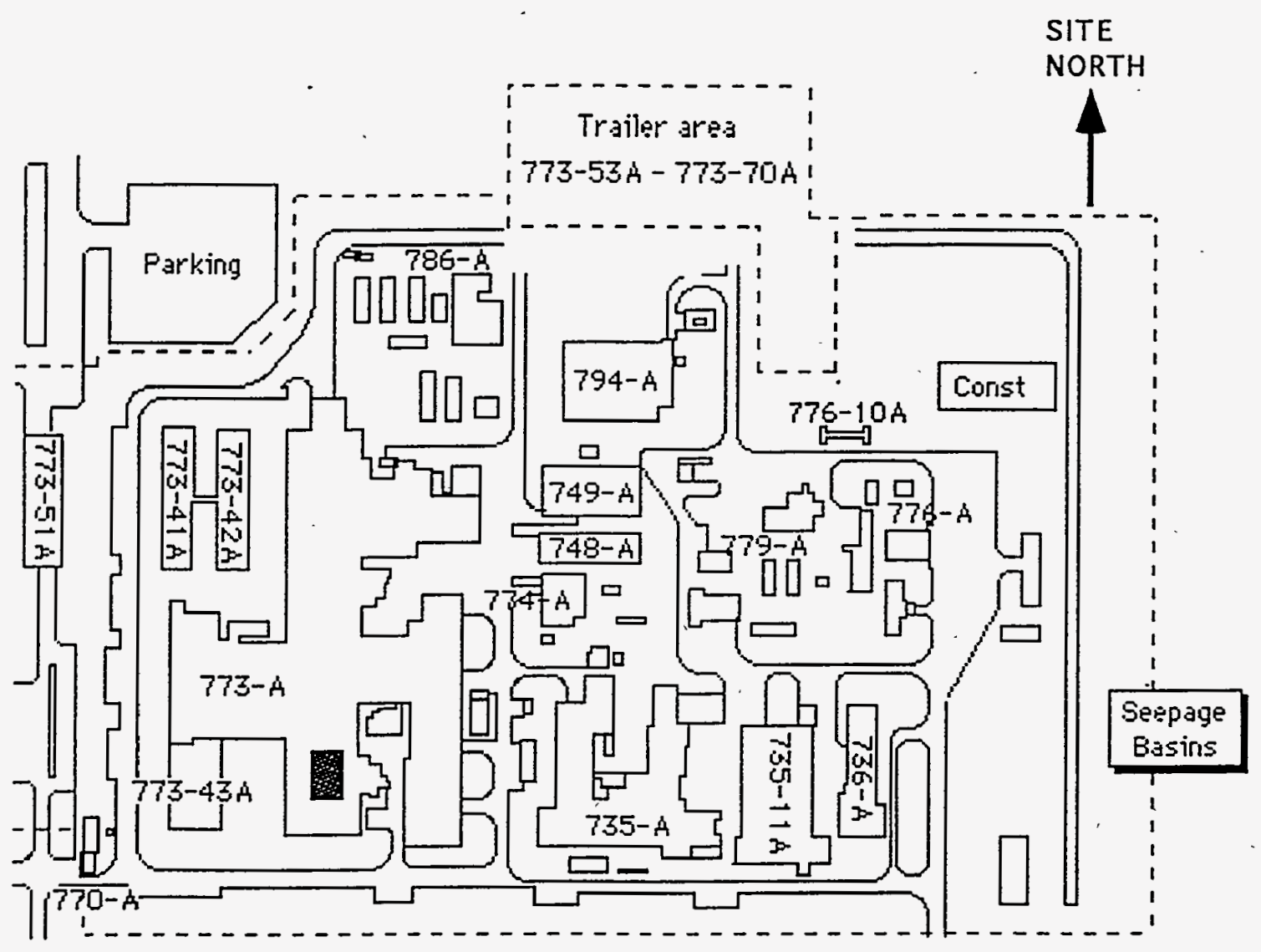

Proposed MOX Pellet fabrication/rodfill location 


\section{ATTACHMENT 5}

\section{CATEGORY 1 FACILITY BLOCK FLOW DIAGRAM}




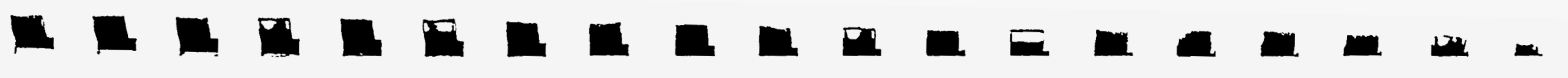

ATTACHMENT 5

PROPOSED DEMONSTRATION MOX FUEL FABRICATION BLOCK FLOW DIAGRAM - CAT. 1 OPTION

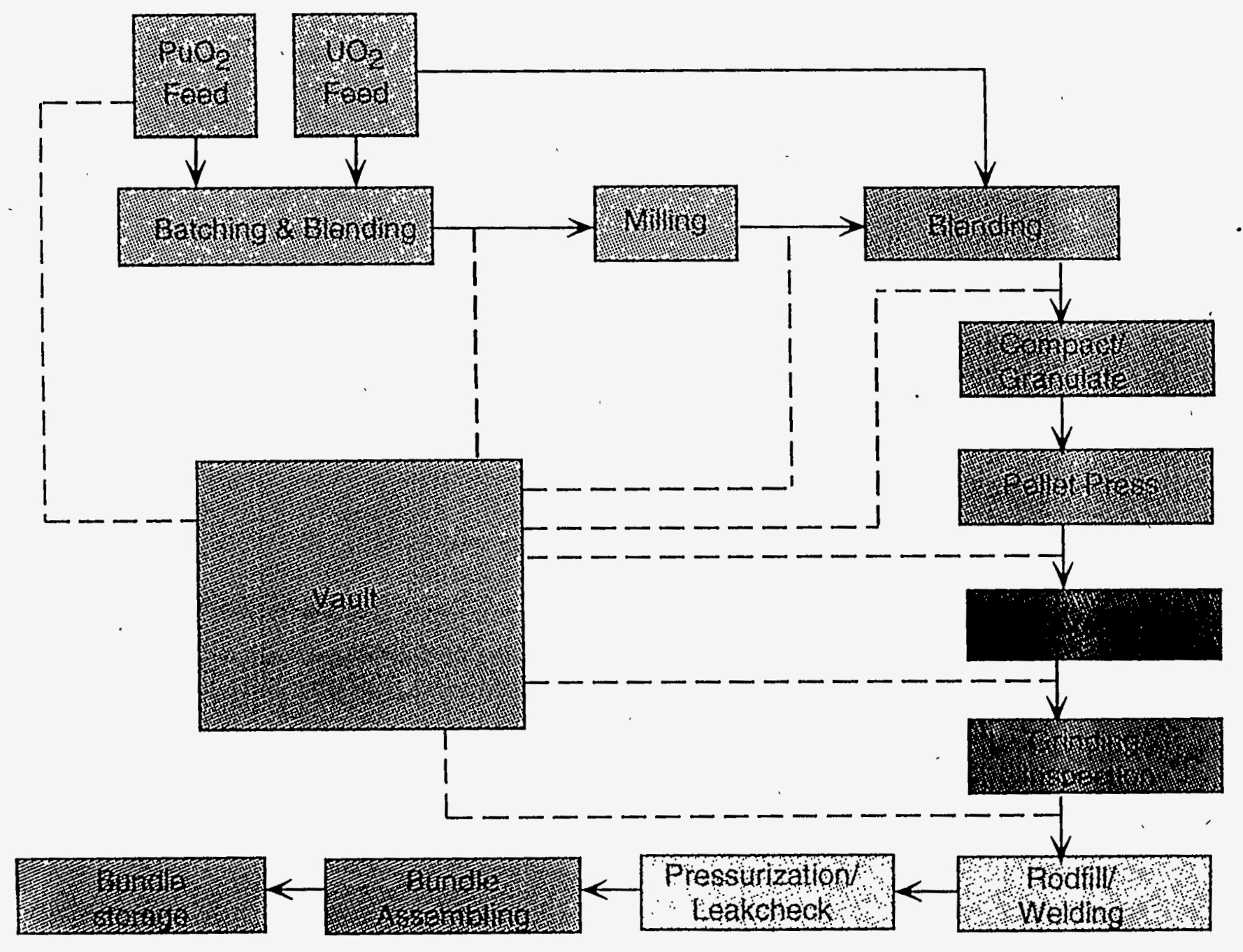




\section{ATTACHMENT 6}

NON-CATEGORY 1 FACILITY OPTION

BLOCK FLOW DIAGRAM 

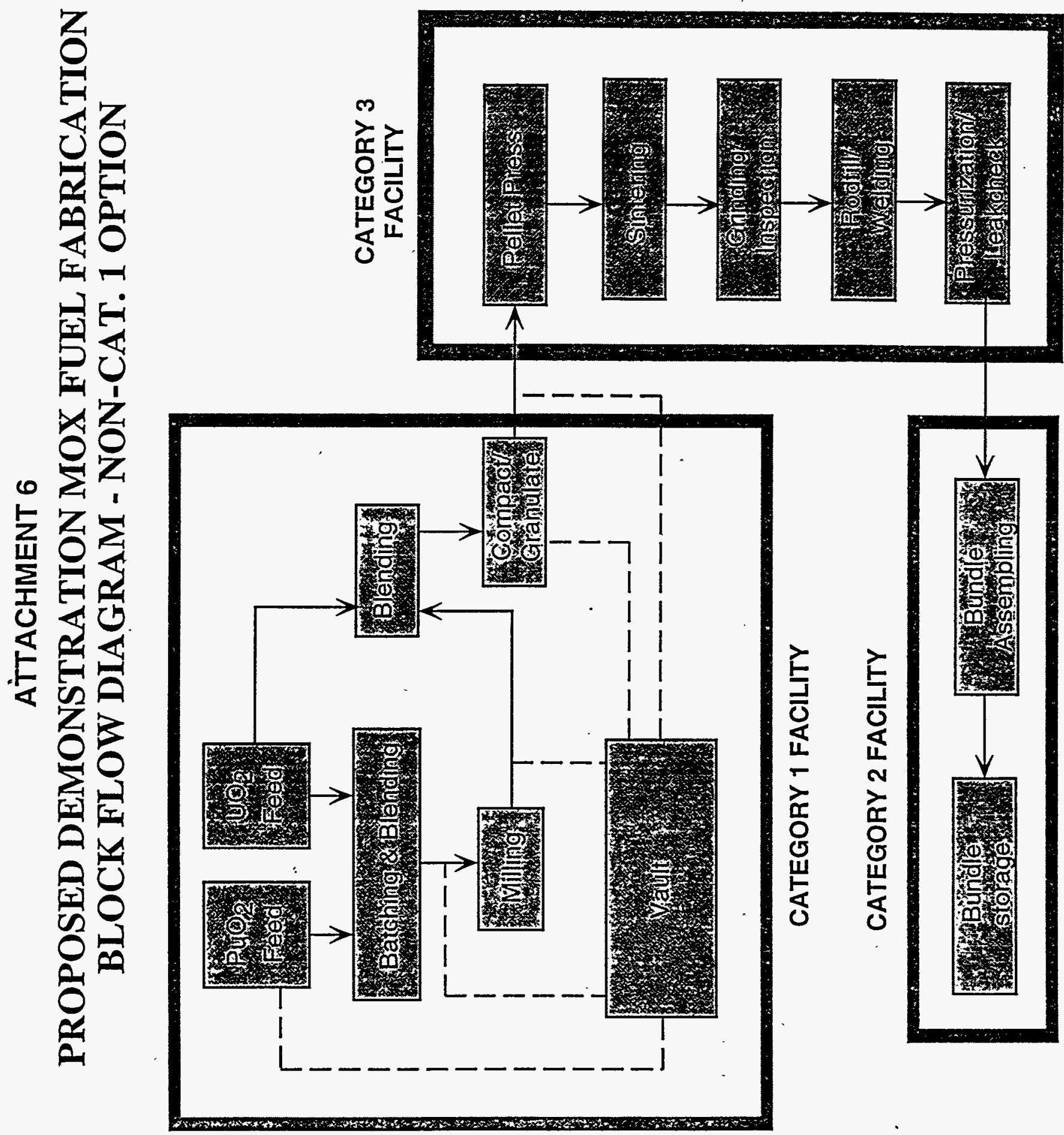


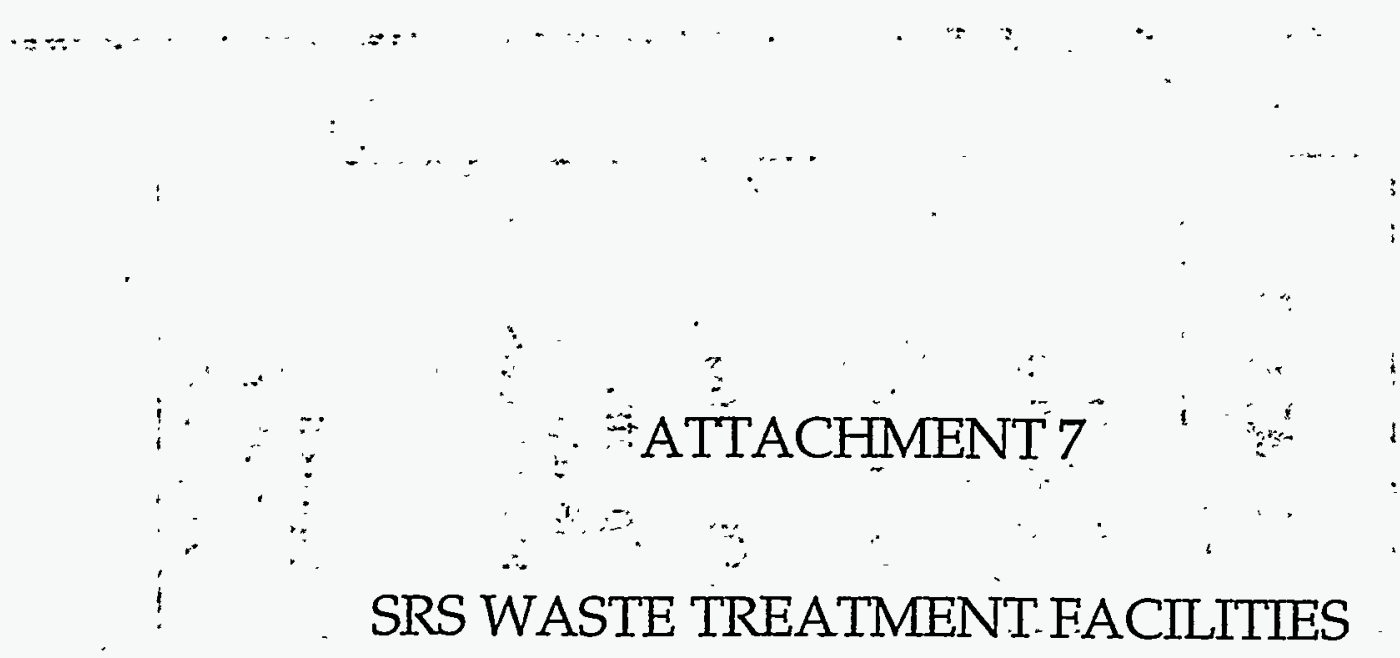

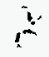




\section{ATTACHMENT 7 SRS Facilities for Disposal of Nuclear Waste}

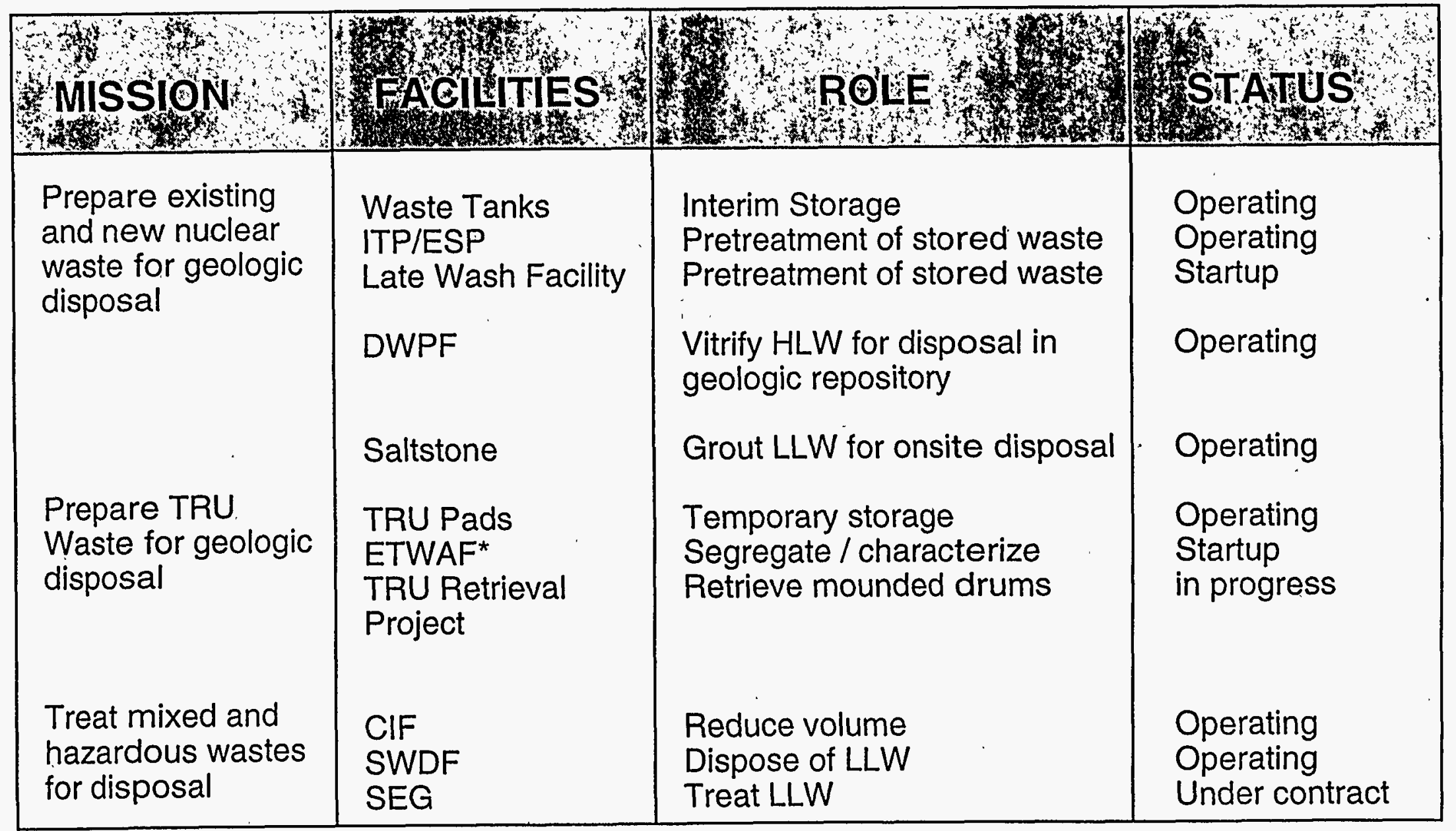

*ETWAF is Experimental TRU Waste Assay Facility 